\title{
Tax Avoidance Practices: Is it Only Affected by Financial Performance?
}

\author{
Carliana Irmaslian ${ }^{1}$, Veni Soraya Dewi ${ }^{2}$, Faqiatul Mariya Waharini ${ }^{3}$ \\ \{venisorayadewi@ummgl.ac.id ${ }^{2}$, maria.waharini@gmail.com ${ }^{3}$ \} \\ Faculty of Economics and Business, Universitas Muhammadiyah Magelang ${ }^{1,2}$ \\ Faculty of Islamic Economics and Business, IAIN Salatiga ${ }^{3}$
}

\begin{abstract}
Tax avoidance is an effort to reduce the tax that is done legally and securely for taxpayers because it does not conflict with the taxation provisions. The study aims to test empirically about the influence of Profitability, Capital Intensity, Inventory Intensity, and Thin Capitalization against tax avoidance. The research methods used are quantitative methods. The population in this research is all manufacturing companies listed on the Indonesia Stock Exchange (IDX) period 2015-2018. Data retrieval as a sample in this study uses purposive sampling. The Total number of companies used in the sample is 43 manufacturing companies. Data was obtained from the financial statements of 43 manufacturing companies listed on the Indonesia Stock Exchange from 2015 to 2018. The data analysis methods in this study used multiple linear regression and classical assumption tests including descriptive statistical trials, test normality, multicholinerity tests, autocorrelation tests and heteroskedastisity tests. The hypothesis testing was conducted using a coefficient of determination (R2) test, $\mathrm{F}$ test, and T test. The results showed that profitability and Capital Intensity have a negative impact on the company's tax evasion. Meanwhile, Inventory Intensity, and Thin Capitalization have no effect on the company tax avoidance.
\end{abstract}

Keywords: Profitabilty, Capital Intensity, Inventory Intensity, Thin Capitalization, Tax Avoidance

\section{Introduction}

Tax is one of the primary sources of income in Indonesia. Taxes play a role in supporting the development of a country. Levies and taxes can fund regional developments and create community welfare [1]. Based on data released by the Directorate General of Taxes, every year, the target of state tax revenues tends to increase. However, in its realization, during 2015-2018, the set target has never been achieved. The tax revenue target that has not been achieved indicates that tax collection in Indonesia has not been carried out optimally. One of the obstacles to optimizing tax revenue by the government is tax avoidance or everything that companies do to reduce the company's tax costs [2]. Tax avoidance is an activity carried out by taxpayers to minimize taxes owed where the activities carried out are still within the framework of laws and regulations [3].

Tax avoidance is a contradiction between the state and the company. For the state, taxes are a source of income, so the government is trying to increase tax revenues according to the State Budget [4]. However, tax is a burden for the company that will reduce net income; the company does tax avoidance by minimizing tax payments. 
Based on this case, it shows that there are several ways for companies to avoid tax. Tax avoidance is intended, so that small companies bear the tax burden. Several factors influence a company in paying taxes. According to Dwiyanti \& Jati [5], the factors that influence tax avoidance are profitability, capital intensity, and inventory intensity. Andhari \& Sukartha [6] shows that profitability harms tax avoidance. Meanwhile, the study by Dwiyanti \& Jati [5] states that profitability through ROA indicators has a positive effect on tax avoidance. Dwiyanti \& Jati [5] shows that capital intensity has a positive impact on tax avoidance. Meanwhile, research by Muzakki [7] shows that capital intensity harms tax avoidance. Inventory intensity or inventory intensity is how much the company invests in its assets in the form of inventory intensity. Dwiyanti \& Jati [5] stated that inventory intensity has a positive effect on tax avoidance. Meanwhile, research conducted by Darmawan \& Sukartha [8], and Siregar \& Widyawati [9] showed that inventory intensity did not affect tax avoidance.

This research is a development of Dwiyanti \& Jati [5] research on the effect of profitability, capital intensity and inventory intensity on tax avoidance. The difference between this research and the research of Dwiyanti \& Jati [5], firstly, this study adds a thin capitalization variable. Second, the research year used is from 2015 to 2018. Third, this study uses the Current ETR measurement tool for measuring tax avoidance. This study aims to empirically examine the effect of Profitability, Capital Intensity, Inventory Intensity, and Thin Capitalization on Tax Avoidance.

\section{Literature Review}

\subsection{Agency Theory}

Agency theory explains the conflict that will arise between shareholders and company management. The separation between shareholders and company management can cause problems, including the possibility of managers taking actions that are not under the wishes or interests of the principal. This conflict is called the agency problem or agency problem [10]. In the self-assessment system, the taxpayer acts as an agent for implementing tax obligations. The tax authorities act as the principal in the agency relationship. Taxpayers try to minimize the tax burden to protect their interests. Taxpayers' efforts to legally reduce the tax burden are tax avoidance [11].

\subsection{Tax avoidance}

Tax avoidance is an effort to reduce taxes that are carried out legally and safely for taxpayers because it does not conflict with tax provisions, where the methods and techniques used tend to take advantage of the weaknesses contained in tax laws and regulations to reduce the amount of tax payable [12].

\subsection{Profitability}

Profitability is a determining factor in the tax burden because companies with higher profits will pay more taxes. On the other hand, companies with low-profit levels will pay lower taxes or even not pay taxes if they experience losses. With a tax compensation system, losses can reduce tax amounts that must be borne in the following year [13]. 


\subsection{Capital Intensity}

Capital intensity ratio is a company's investment activity associated with an investment in fixed assets and inventories. Capital intensity is proxied using the fixed asset intensity ratio. Fixed asset intensity is the ratio of total fixed assets to total assets owned by the company. The higher the capital intensity, the higher the company invests its assets in fixed assets [14].

\subsection{Inventory Intensity}

Inventory Intensity Ratio shows the effectiveness and efficiency of the company to manage its investment in inventory which is reflected in the number of times the stock is rotated during a specific period [15]. According to Harahap \& Jiwana [16], this ratio describes the relationship between the volume of goods sold and the volume of inventory on hand. It is used as a measure of company efficiency.

\subsection{Thin Capitalization}

Thin capitalization refers to investment decisions by companies in funding business operations by prioritizing debt financing rather than using the equity in their capital structure [17]. The practice of thin capitalization is based on differences in the treatment of tax regulations on interest [18]. The cost of interest is a deduction element in the calculation of taxable income.

\subsection{Framework and Hypothesis Development}

The company's profitability describes whether or not the company's management is effective in managing the company so that it can achieve the expected target of the company owner. The higher the company's profit, the greater the tax burden that must be paid. A negative relationship exists between increased profitability and tax liability. This is due to the company's desire to increase its profitability, but at the same time, the company wants to reduce its tax payments so that company profits remain high [8], 2014). Based on this, companies that tend to avoid tax are companies that have high profitability.

H1. Profitability has a positive effect on tax avoidance.

Capital intensity or capital intensity ratio is a company's investment activity associated with the fixed-asset investment. The capital intensity ratio can show the efficiency of using assets to generate sales [19]. Agency theory explains the separation of the interests of the principal and the agent, which results in the company's operational activities being carried out by the management. Managers will invest company funds in fixed assets to take advantage of the depreciation as a tax deduction. Companies with a high capital intensity have a high depreciation expense on assets [5]. Companies that use capital intensity in reducing profits tend to avoid tax. H2. Capital intensity has a positive effect on tax avoidance.

Inventory Intensity Ratio shows the effectiveness and efficiency of the company to manage its investment in inventory which is reflected in the number of times the stock is rotated during a specific period [15]. The company's investment in fixed assets incurs inventory costs (purchase costs, conversion costs, and other costs incurred until the inventory are in a condition and place that is ready to be sold or used). The price of stocks is a deduction from taxable income. When the company's taxable income decreases, the tax burden that must be paid by the company also 
decreases. This is contrary to the government's interests as a principle that hopes that tax revenues will be carried out optimally. However, the company maintains its interest so that the tax burden paid remains low. The company tends to do tax avoidance through inventory intensity.

H3. Inventory Intensity has a positive effect on tax avoidance.

Thin Capitalization refers to investment decisions by companies in funding business operations by prioritizing debt financing rather than using the equity in their capital structure [17]. Agency theory uses three assumptions of human nature that encourage someone to take opportunistic actions to maintain their interests. When a company prioritizes debt financing in its capital structure, it creates a tax incentive in interest expense which can be treated as a deduction from taxable income. This difference in the treatment of interest and dividends can be a gap for opportunistic actions so that companies tend to do tax avoidance. As a result, the tax burden paid by the company is reduced. This is supported by research by Olivia \& Dwimulyani [20], showing that thin Capitalization positively affects tax avoidance. Based on this description, the proposed hypothesis is:

H4. Thin Capitalization has a positive effect on tax avoidance.

The Tax Avoidance research model is presented in Fig. 1.

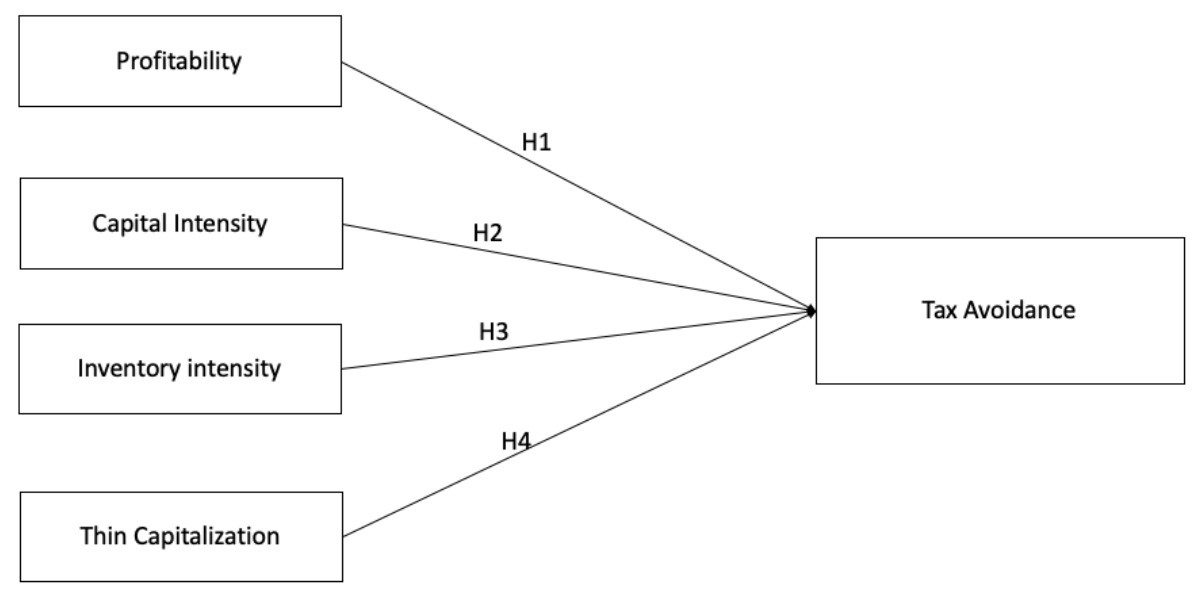

Fig. 1. Tax avoidance research model

\section{Method}

This study uses data on the financial statements of manufacturing companies listed on the Indonesia Stock Exchange in 2015-2018. The sampling technique in this study used a purposive sampling technique. Operational Variables is presented in Table 1. 
Table 1. Operational Variables

\begin{tabular}{ccc}
\hline Variables & Measurement & Scale \\
\hline Tax Avoidance $(\mathrm{Y})$ & Current ETR $=\frac{\text { Current Expense } i, t}{\text { Pre tax income } i, t}$ & Ratio \\
Profitability $\left(\mathrm{X}_{1}\right)$ & ROA $=\frac{\text { Pre tax income }}{\text { Total Assets }} \times 100 \%$ & Ratio \\
Capital Intensity $\left(\mathrm{X}_{2}\right)$ & CAPIN $=\frac{\text { Net Fixed Asset }}{\text { Total Assets }}$ & Ratio \\
Inventory Intensity $\left(\mathrm{X}_{3}\right)$ & Inventory Intensity $=\frac{\text { Total Inventory }}{\text { Total Asset }}$ & Ratio \\
Thin Capitalization $\left(\mathrm{X}_{4}\right)$ & TCAP $=\frac{\text { Total Liability }}{\text { Total Equity }}$ & Ratio \\
\hline
\end{tabular}

Source: [21], [22], [13], [23], [17]

The data analysis method in this study used multiple linear regression and classical assumption tests, including descriptive statistical tests, normality tests, multicollinearity tests, autocorrelation tests and heteroscedasticity tests. The regression equation model is formulated as follows:

$T A=\alpha+\beta 1$ Prof $+\beta 2 C I+\beta 3 I I+\beta 4 T C+\varepsilon$

Information :

$$
\begin{array}{ll}
\alpha & =\text { Constant } \\
\beta & =\text { Coeffisient } \\
\text { TA } & =\text { Tax Avoidance } \\
\text { Prof } & =\text { Profitability } \\
\text { CI } & =\text { Capital Intensity } \\
\text { II } & =\text { Inventory Intensity } \\
\text { TC } & =\text { Thin Capitalization } \\
\varepsilon & =\text { Residual regression }
\end{array}
$$

\section{Result and Discussion}

\subsection{Assumption test}

The number of research samples is 172. Classical assumption tests include descriptive statistical tests, normality tests, multicollinearity tests, autocorrelation tests and heteroscedasticity tests [24]. The test results show that the data meet the classical assumption test criteria required.

\subsection{Multiple Regression Analysis}

A multiple regression model is used to determine the effect of the independent variable on the dependent variable. Based on the multiple linear regression analysis results, the regression coefficient values are obtained, which are presented in Table 2. 
Table 2. Multiple Regression Result

\begin{tabular}{|c|c|c|c|c|c|c|}
\hline & \multirow[t]{2}{*}{ Model } & \multicolumn{2}{|c|}{ Unstandardized Coefficients } & $\begin{array}{l}\text { Standardized } \\
\text { Coefficients } \\
\end{array}$ & \multirow[t]{2}{*}{$\mathrm{t}$} & \multirow[t]{2}{*}{ Sig. } \\
\hline & & $\mathrm{B}$ & Std. Error & Beta & & \\
\hline \multirow[t]{5}{*}{1} & (Constant) & .134 & .034 & & 3.958 & .000 \\
\hline & LN_PROF & -.054 & .010 & -.448 & -5.597 & .000 \\
\hline & $\mathrm{CI}$ & -.090 & .044 & -.162 & -2.031 & .044 \\
\hline & II & .068 & .067 & .077 & 1.010 & .314 \\
\hline & LN_TC & -.009 & .008 & -.086 & -1.068 & .287 \\
\hline
\end{tabular}

a. Dependent Variable: TA

Based on the results of the regression coefficients in Table 2, the following regression equation is obtained.

$T A=0.134-0.054 P R O F-0.090 C I+0.068 I I-0.097 T C+e$

\subsection{Coefficient of Determination Analysis}

The coefficient of determination is used to determine how far the research model's ability to explain the variation of the dependent variable show in Table 3.

Table 3. Coefficient of Determination Analysis Result

\begin{tabular}{lllll}
\hline Model & R & R Square & Adjusted R Square & Std. Error of the Estimate \\
\hline 1 & $.462^{\mathrm{a}}$ & .214 & .195 & .0751226 \\
\hline a. Predictors: (Constant), LN_TC, CI, II, LN_PROF & \\
\hline
\end{tabular}

Based on the coefficient of determination in Table 3, the adjusted $\mathrm{R}$ square is 0.195 . This means that the ability of profitability, capital intensity, inventory intensity, and thin capitalization in explaining tax avoidance is 0.195 or $19.5 \%$. In comparison, the remaining $80.5 \%(100 \%-19.5 \%)$ is defined by other factors outside the research model.

\subsection{F test}

The $\mathrm{F}$ test is used to show that the model used in this study is fit. The results of the $\mathrm{F}$ statistical test is presented in Table 4.

Table 4. F test

\begin{tabular}{|c|c|c|c|c|c|c|}
\hline & \multirow{2}{*}{$\begin{array}{l}\text { Sum of Squares } \\
.256\end{array}$} & \multirow{2}{*}{$\frac{\mathrm{df}}{4}$} & \multirow{2}{*}{$\begin{array}{l}\text { Mean Square } \\
.064\end{array}$} & \multirow{2}{*}{$\begin{array}{l}\mathrm{F} \\
11.349\end{array}$} & \multirow{2}{*}{$\begin{array}{l}\text { Sig. } \\
.000^{\mathrm{b}}\end{array}$} \\
\hline \multirow{3}{*}{1} & $\begin{array}{ll}\text { Model } \\
1 & \text { Regression }\end{array}$ & & & & & \\
\hline & & .942 & 167 & .006 & & \\
\hline & $\begin{array}{l}\text { Regression } \\
\text { Residual } \\
\text { Total }\end{array}$ & 1.199 & 171 & & & \\
\hline
\end{tabular}

a. Dependent Variable: TA

b. Predictors: (Constant), LN_TC, CI, II, LN_PROF 


\subsection{T-test}

The t-statistical test shows how far the influence of the independent variables explains the dependent variables. The statistical results of the t-test can be seen in Table 5.

Table 5. T-test

\begin{tabular}{|c|c|c|c|c|c|c|c|}
\hline & \multirow[t]{2}{*}{ Model } & \multicolumn{2}{|c|}{$\begin{array}{l}\text { Unstandardized } \\
\text { Coefficients }\end{array}$} & \multirow{2}{*}{$\begin{array}{c}\text { Standardized } \\
\text { Coefficients } \\
\text { Beta }\end{array}$} & \multirow[t]{2}{*}{$\mathrm{t}$} & \multirow[t]{2}{*}{ Sig. } & \multirow[t]{2}{*}{ Result } \\
\hline & & $\mathrm{B}$ & Std. Error & & & & \\
\hline \multirow[t]{5}{*}{$1 \mathrm{H} 1$} & (Constant) & .134 & .034 & & & .000 & \\
\hline & LN_PROF & -.054 & .010 & -.448 & -5.597 & .000 & H1 confirmed \\
\hline & CI & -.090 & .044 & -.162 & -2.031 & .044 & H2 confirmed \\
\hline & II & .068 & .067 & .077 & 1.010 & .314 & H3 not confirmed \\
\hline & LN_TC & -.009 & .008 & -.086 & -1.068 & .287 & H4 not confirmed \\
\hline
\end{tabular}

a. Dependent Variable: TA

Based on the test results indicate that profitability harms tax avoidance. The amount of profitability suggests that the company's performance is good and can carry out operational activities by its responsibilities. When the company has a good performance, the company can manage the income and taxes that must be paid. Tax planning done well on income will produce an optimal tax burden [25].

The test results show that capital intensity hurts tax avoidance. When the company has a significant capital intensity, the company's operational activities will increase and generate profits for the company. Large profits can meet the government's interests as a tax collector, so the realization of tax revenue becomes more optimal.

The test results show that inventory intensity does not affect tax avoidance. This happens because, usually, the tax law does not provide tax incentives for companies that have extensive inventories of goods [26].

The results of this test indicate that thin capitalization does not affect tax avoidance. This is possible because the thin capitalization of manufacturing companies in Indonesia does not create an interest expense in debt for tax avoidance purposes. However, the deficit appears for other purposes such as expansion and company operations [27].

\section{Conclusion}

Profitability and Capital Intensity harm tax avoidance. Meanwhile, Inventory intensity and thin capitalization do not affect tax avoidance. Manufacturing companies tend to avoid tax even when the company's performance and capital are small, even though the tax base is also small. These results have implications for users of financial statements, especially auditors and the government, to pay more attention to calculating the tax base for companies so that indications of tax avoidance can be detected. 


\section{References}

[1] P. W. Arianandini and I. W. Ramantha, "Pengaruh Profitabilitas, Leverage, dan Kepemilikan Institusional Pada Tax Avoidance," E-Jurnal Akunt., vol. 22, p. 2088, 2018, doi: 10.24843/eja.2018.v22.i03.p17.

[2] I. M. E. Darsana, I. P. G. Diatmika, and P. S. Kurniawan, "Pengaruh Pengungkapan Corporate Social Responsibility ( CSR ), Capital Intensity Dan Proporsi Komisaris Independen Terhadap Agresivitas Pajak," e-jurnal S1 Ak Univ. Pendidik. Ganesha, vol. 8, no. 2, pp. 1-12, 2017.

[3] T. D. Tarida and A. B. Prasetyo, "Penghindaran Pajak Terhadap Nilai Perusahaan dan Biaya Agensi dengan Transparansi Informasi sebagai Variabel Pemoderasi," Jurnal Analisis Bisnis Ekonomi, vol. 16, no. 2, pp. 18-38, 2018.

[4] S. D. Pinareswati and T. Mildawati, "Pengaruh Pengungkapan Csr, Capital Intensity, Leverage , Profitabilitas, Dan Inventory Intensity Terhadap Agresivitas Pajak," J. Ilmu dan Ris. Akunt., vol. 9, no. 9, pp. 1-23, 2020.

[5] I. A. I. Dwiyanti and I. K. Jati, "Pengaruh Profitabilitas, Capital Intensity, dan Inventory Intensity pada Penghindaran Pajak," E-Jurnal Akunt., vol. 27, p. 2293, 2019, doi: 10.24843/eja.2019.v27.i03.p24.

[6] P. A. S. Andhari and I. M. Sukartha, "Pengaruh Pengungkapan Corporate Social Responsibility , Profitabilitas , Inventory Intensity , Capital Intensity dan Leverage pada Agresivitas Pajak" Udayana, E-jurnal Akunt. Univ., vol. 18, no. 2017, pp. 2115-2142, 2017.

[7] M. R. Muzakki and D. Darsono, "Pengaruh Corporate Social Responsibility dan Capital Intensity terhadap Penghindaran Pajak," Diponegoro J. Account., vol. 4, no. 3, pp. 1-8, 2015, doi: 10.22219/jaa.v1i1.6947.

[8] I. G. H. Darmawan and I. M. Sukartha, "Pengaruh Penerapan Corporate Governance, Leverage, Return on Assets, dan Ukuran Perusahaan pada Penghindaran Pajak," E-Jurnal Akunt. Univ. Udayana., vol. 9, no. 1, pp. 143-161, 2014, doi: 10.26623/slsi.v18i2.2296.

[9] R. Siregar and D. Widyawati, "Pengaruh Karakteristik Perusahaan Terhadap Penghindaran Pajak pada Perusahaan Manufaktur di Bei," J. Ilmu Ris. Akunt., vol. 5, no. 2, pp. 2460-0585, 2016.

[10] M. C. Jensen and W. H. Meckling, "Theory of the Firm: Managerial Behavior, Agency Cost and Ownership Structure," J. Financ. Econ. 3, no. 3, pp. 305-360, 1976.

[11] Mardiasmo, Perpajakan Edisi Revisi. Yogyakarta: Andi, 2003.

[12] C. A. Pohan, Manajemen Perpajakan : Strategi Perencanaan Pajak \& Bisnis. PT Gramedia Utama, 2013.

[13] E. F. Rodríguez and A. M. Arias, "Do Business Characteristics Determine an Effective Tax Rate?," Chinese Econ., vol. 45, no. 6, pp. 60-83, Nov. 2012, doi: 10.2753/CES1097-1475450604.

[14] D. Indradi, "Pengaruh Likuiditas, Capital Intensity terhadap Agresivitas Pajak ( Studi empiris perusahanManufaktur sub sektor industri dasar dan kimia yang terdaftar di BEI tahun 2012-2016.)," J. Akunt. Berkelanjutan Indones., vol. 1, no. 1, p. 147, 2018, doi: 10.32493/jabi.v1i1.y2018.p147167.

[15] H. T. Setijaningsih and C. D. Pratiwi, "Pengaruh Beberapa Variabel terhadap Pemilihan Metode Penilaian Persediaan pada Perusahaan Manufaktur," THE WINNERS, vol. 10, no. 1, pp. 49-65, 2009, doi: https://doi.org/10.21512/tw.v10i1.716.

[16] R. K. Harahap and D. M. Jiwana, "Analisis Faktor-faktor yang Berpengaruh terhadap Pemilihan Metode Akuntansi Persediaan pada Perusahaan Manufaktur di Bursa Efek Jakarta," Media Ris. Akuntansi, Audit. Inf., pp. 74-95, 2009, doi: 10.25105/mraai.v9i3.738.

[17] G. Taylor and G. Richardson, "The determinants of thinly capitalized tax avoidance structures: Evidence from Australian firms," J. Int. Accounting, Audit. Tax., vol. 22, no. 1, pp. 12-25, 2013.

[18] N. S. Nuraini and M. Marsono, "Analisis Faktor-Faktor Yang Mempengaruhi Thin Capitalization Pada Perusahaan Multinasional Di Indonesia," Diponegoro J. Account., vol. 3, no. 3, pp. 1-9, 2014.

[19] M. Yoehana, "Analisis Pengaruh Corporate Social Responsibility Terhadap Agresivitas Pajak," Diponegoro J. Account., pp. 1-62, 2013.

[20] I. Olivia and S. Dwimulyani, "Pengaruh Thin Capitalization dan Profitabilitas Terhadap Penghindaran Pajak dengan Kepemilikan Institusional sebagai Variabel Moderasi," Pros. Semin. 
Nas. Pakar ke 2 Sos. dan Hum., pp. 1-10, 2019.

[21] M. Hanlon and S. Heitzman, "A Review of Tax Research," J. Account. Econ., vol. 50, pp. 127-178, Jul. 2010, doi: 10.1016/j.jacceco.2010.09.002.

[22] E. F. Brigham and J. F. Houston, Essentials of Financial Management Dasar-Dasar Manajemen Keuangan. Salemba Emoat, 2011.

[23] S. Gupta and K. Newberry, "Determinants of the variability in corporate effective tax rates: Evidence from longitudinal data," J. Account. Public Policy, vol. 16, no. 1, pp. 1-34, 1997.

[24] I. Ghozali, plikasi Analisis Multivariate Dengan Program IBM SPSS 25, 9th ed. Semarang: Badan Penerbit Universitas Diponegoro, 2018.

[25] S. Chen, X. Chen, Q. Cheng, and T. Shevlin, "Are family firms more tax aggressive than non-family firms?," J. financ. econ., vol. 95, no. 1, pp. 41-61, 2010, doi: 10.1016/j.jfineco.2009.02.003.

[26] A. P. Romadhina, "Pengaruh Beban Iklan Dan Intensitas Persediaan Terhadap Agresivitas Pajak the," J. Econ. Manag. Sci., vol. 2, no. 1, pp. 1-13, 2017.

[27] N. Komariah, "Pengaruh Thin Capitalization dan Karakteristik Eksekutif dengan Kompensasi Manajamen Sebagai Pemoderasi Terhadap Penghindaran Pajak.," Skripsi Univ. Islam Negeri Syarif Hidayatullah., 2017. 